\title{
IRRELEVANCE OF INFLATION: THE 20 FAMA-FRENCH STOCKS
}

\author{
DOI: 10.17261/Pressacademia.2021.1379 \\ JBEF- V.10-ISS.1-2021(1)-p.1-11
}

\section{Samih Antoine Azar}

Haigazian University, Faculty of Business Administration \& Economics, Mexique Street, Kantari, Beirut, Lebanon. samih.azar@haigazian.edu.lb, ORCID: 0000-0003-4111-797X

Date Received: November 25, $2020 \quad$ Date Accepted: March 2, 2021
To cite this document
Azar, S. A., (2020). Irrelevance of inflation: the 20 Fama-French stocks. Journal of Business, Economics and Finance (JBEF), V.10(1), p. 1-11.
Permanent link to this document: $\underline{\text { http://doi.org/10.17261/Pressacademia.2021.1379 }}$
Copyright: Published by PressAcademia and limited licensed re-use rights only.

\section{ABSTRACT}

Purpose - The relation between inflation and stock returns has been widely scrutinized. Its importance transcends finding just a simple relation, and has repercussions on the conduct of monetary policy. Theoretically, the relation should be positive and one-to-one. However, early on, the empirical relation was found to be statistically significantly negative. This paper contributes to the theoretical and empirical debate. The null hypothesis is that inflation is irrelevant to stock returns. Therefore, neither a positive theoretical, nor a negative empirical relation, should robustly hold. This position is in accordance to the basic principles of modern corporate finance, which state that the real and nominal equity values are equal.

Methodology - The paper starts with simple correlations and presents the probability distributions and histograms of all variables. All distributions are characterized by significant outliers. A theoretical model that excludes inflation is introduced, and the statistical significance of including inflation is tested. The quest covers the 20 Fama-French stock portfolios, classified by their percentiles of equity values. Hence, both bilateral and multilateral regressions are carried out.

Findings - Initially bilateral correlations were found to be negative consistent with the early empirical evidence. However, by using robust standard errors, robust least squares, and quantile regressions, the evidence is totally reversed. There is strong support for the irrelevance of inflation. This is true if the investor is sophisticated, i.e. she does not give too much attention to simple bilateral correlations, if she utilizes advanced economic procedures like robust least squares and quantile regressions, if she adjusts for residual autocorrelation and heteroscedasticity, and if she incorporates fundamental variables in the estimation process.

Conclusion - Hence the prima facie evidence of non-neutrality is challenged by this paper's analysis. In opposition to the conviction of many economists, and despite their inherent resistance, the paper argues for inflation irrelevance.

Keywords: inflation irrelevance, Fama-French stocks, model of stock returns, fallacious evidence, robust least squares, quantile regressions, bilateral and multilateral relations.

JEL Codes: G12, E31, C21, C22

\section{INTRODUCTION}

The hypothesis of a significant impact of inflation on stock returns has been abundantly tested. Such a relation is particularly crucial for the conduct of monetary policy. If there is a relation, then the financial markets would respond instantaneously to inflation shocks, and hence, they may indicate early on the appropriate forecast of equity prices, their link to economic activity, and determine the ensuing stance of monetary policy. This is true because central banks monitor scrupulously the behavior of financial and capital assets, and base their monetary reaction on the upheavals in these markets. Theoretically the sign of the relation is ambiguous. Both a negative supply shock and a positive demand shock predict higher consumer prices. However, a supply shock is accompanied by a fall in output, whereas a demand shock occurs concurrently with an improvement in business. It is not clear which one dominates the other. Maybe, on average, both shocks counterbalance and eliminate each other. Hence economists have favored either a negative or a positive sign, while teachers of corporate finance would opt, in general, to privilege the independence of both variables. Chronologically the negative sign has been empirically found by researchers before a positive 
sign $^{1}$, and was justified by more than one channel of transmission. However, historically, the positive relation prevailed theoretically before the empirics (Fisher, 1930). The Fisher hypothesis states that the nominal interest rate is the summation of a real expected interest rate with an expected inflation rate. The real rate is approximately constant, and represents the secular marginal product of capital. This implies that the nominal interest rate varies one-to-one with inflation. Moreover, the Generalized Fisher Hypothesis specifies that stock returns should also vary one-to-one with inflation. More than that, stocks, being claims on real assets, should be a perfect hedge against inflation ${ }^{2}$. One particular and additional justification of a positive relation is to refer to a version of the Phillips curve, if stock prices predict positively future activity, and negatively unemployment. The seminal contribution of Engle \& Granger (1987) on cointegration facilitated the search of a long run cointegration relation between stock market indexes and the price level. Early research using cointegration has been carried out by Boudoukh and Richardson (1993), Ely and Robinson (1997), Anari and Kolari (2001), and Crosby (2001). Boudoukh and Richardson (1993) find a positive relation but the impact is less than 1 , around 0.43 . Crosby finds an even smaller impact of 0.2 . Later research on cointegration can be found in Hasan (2008), Boamah (2017) and especially in Al-Nassar and Bhatti (2019). Surprisingly Hasan (2008) documents a bidirectional causality between stocks and inflation, while Harper and Jin (2012) find a negative relation that has a magnitude of -6 for Indonesia. Very recently, Eldomiaty et al. (2020) also find a negative and significant impact for the US market. The presence of cointegration implies an Error Correction Model that contradicts weak form market efficiency, because stock returns become predictable by the lagged error-correction variable. Therefore, the lack of evidence on cointegration may simply be due to financial market efficiency, and should be expected to happen on average. To reconcile the evidence one might posit that there is a negative relation in the short run, and a positive relation in the long run, or vice versa. For example, a negative supply shock may be gradually dissipated as employment and output return to their natural levels. And a positive demand shock may be gradually eradicated as real money balances adjust. It is difficult to know theoretically the direction of the change. Why should the impact be different in sign? This is where a third generation of empirical studies, and which is among the most recent, comes about. One starts from the elementary principles of corporate finance (Brealey et al., 2017). Nominal cash flows are discounted by nominal rates, and real cash flows are discounted by real rates, both producing the same present value. Since stocks are Net Present Values (NPV), they should be insensitive to inflation. How, then, can one explain the empirical findings, of the difference in signs between short run and long run? Azar (2010) has argued that the empirical evidence is flawed and biased, either because of omitted fundamental variables, or from the specification of the model. He finds that the bias applies to inflation, expected inflation, unexpected inflation, and even for inflation uncertainty (Azar, 2013, 2020a). Azar (2014a) adds to the list of relevant variables the US dollar, the choice of the econometric procedure, and the S\&P 500 stock market index. Azar (2014b) adds further by weighing the time series properties of the variables. Azar (2014b) concludes that the evidence is still strong in support to the irrelevance proposition that inflation has no impact on stock returns. Azar (2015) finds that the relation between the equity premium and inflation is similar to the relation between real stock returns and inflation, i.e. spurious. An econometric critique of the extant specification of such a relation and a statistical proof that it is spurious is available in Azar (2020b).

Moreover, a study on the stocks included in the Dow Jones Industrial Index (DJIA), or Dow stocks, came to the conclusion that inflation is irrelevant and neutral (Azar, 2020c). This is remarkable because most empirical research was undertaken on stock indexes, or their returns, like in Azar (2020d). The use of an index may show inflation neutrality by simple averaging, while the constituent stocks can have distinct sensitivities to inflation. The referenced paper has dismissed these concerns. Inflation is irrelevant to individual stocks and in addition to stock market indexes, and so whatever the econometric procedure adopted, whatever the price index from which the inflation rate is measured, whatever the industry, and whatever the specification of the model. This paper confronts the issue by studying a combination of the 20 Fama-French portfolios, which are classified according to the size of their individual equity values, and reports more evidence in support of inflation irrelevance. The plan of the paper is as follows. In section 2 the mathematical model is introduced. In section 3 the sources of the data are spelled out. Section 4 has 7 subsections. Subsection 4.1 presents the distribution histograms of all the variables, and presents strong evidence for the presence of outliers in all of them, outliers that must be taken into consideration by the econometric technique that is applied. Subsection 4.2 calculates bilateral Pearson correlation coefficients. Subsection 4.3 runs constrained models in case of nominal stock market returns and inflation, estimated with HAC robust standard errors. Subsections 4.4 and 4.5 tackle the same model except that it is estimated respectively by robust least squares and by quantile regressions on the medians. Subsection 4.6

\footnotetext{
${ }^{1}$ See Bodie (1976), Nelson (1976), and Jaffe and Mandelker (1976), followed closely by Fama and Schwert (1977). This initiated an abundance of research, and a huge attempt to explain this negative relation theoretically. Other early empirical studies are Gultekin (1983) and Solnik (1983). ${ }^{2}$ On the theoretical front some invoked taxes (Feldstein, 1980), some posited money or inflation illusion (Modigliani and Cohn, 1979; Campbell and Vuolteenaho, 2004), some reverted to money demand theory and its link to the stock market (Fama, 1981), and some reversed the direction of the relation and explained it by the monetary/fiscal nexus (Geske, and Roll, 1983).
} 
generalizes the model to include additional variables, and this model is called unconstrained, and is estimated by robust least squares, which corrects for outliers in dependent and independent variables. Subsection 4.7 applies quantile regressions to the unconstrained model, while subsection 4.8 discusses the issue of choosing core inflation instead of CPI inflation. Section 5 summarizes and concludes.

\section{THE MATHEMATICAL MODEL}

In the literature there are two mathematical models that compete but that start from the same equilibrium equity value, that with a constant growth in dividends (Williams, 1938; Gordon and Shapiro, 1956; Gordon, 1959; Gordon, 1962).

$$
S=\kappa E(1+g) /(k-g)
$$

Where $S$ is the stock market price, $\kappa=$ payout ratio, $E=$ earnings, $g=$ growth rate, and $k=$ cost of equity, with:

$$
k=r+\pi+h
$$

The real interest rate is $r$, expected inflation is $\pi$, and $h$ is the equity risk premium.

The first application is due initially to Leibowitz et al. (1989) and was used by Jareño and Navarro (2010) and Eldomiaty et al. (2020). The basic equation is for the growth rate of profits $(g)$ that is explained by the real interest rate $r$, with coefficient $\gamma$, and by the expected inflation $\pi$, with coefficient $\lambda$ :

$$
g=g_{0}+\gamma r+\lambda \pi
$$

Replacing this equation in the constant growth formula for a stock, one gets:

$$
d S / S=-D U R(1-\gamma+\partial h / \partial r) d r-D U R(1-\lambda+\partial h / \partial \pi) d \pi
$$

Where $S$ is the stock price, $D U R$ is the duration, and $h$ is the equity risk premium. This equation collapses to the following if the risk premium $h$ is independent of the real interest rate and of expected inflation:

$$
d S / S=-D U R(1-\gamma) d r-D U R(1-\lambda) d \pi .
$$

A $\lambda$ close to 1 means that the firm is able to redirect totally to consumers the change in prices because of its market power, and hence the impact of inflation on stock returns is negligible. Problems with equation (3) is that one usually takes growth in net income as $g$ and it is known that this proxy for growth is very noisy and possibly biased because of accounting standards. Finally a value of $\lambda$ close to 1 may not come only from a firm's market power, but by the absence of money illusion of consumers in competitive markets. What is required is that the price elasticity of demand relative to consumer prices be the same as the price elasticity of demand for the firm's product.

The second mathematical model assumes the following process for $S$ (Fama and French, 2002; Azar, 2013, 2014a, and 2014b):

$$
\begin{aligned}
& G=L O G(S)=L O G[\kappa E(1+g) /(k-g)] \\
& d G=d L O G(S)=d S / S=\left(\mu-0.5 * \sigma^{2}\right) d t+\sigma d z+(\partial G / \partial S)[(\partial S / \partial k) d k+(\partial S / \partial E) d E]
\end{aligned}
$$

Or:

$$
d G=d L O G(S)=d S / S=\left(\mu-0.5 * \sigma^{2}\right) d t+\sigma d z+(1 / S)[(\partial S / \partial k) d k+(\partial S / \partial E) d E]
$$

With:

$$
(1 / S) \partial S / \partial k=-(1 /(k-g)) \text { and }(1 / S) \partial S / \partial E=(1 / E)
$$

The variable $d z$ is a Brownian motion, and $\mu$ is the percent average. Total earnings $E$ are equal to domestic earnings $E_{d}$ plus foreign earnings $E_{f}$. Foreign earnings $E_{f}$ are related to the foreign exchange rate $(X)$ by the equation $E_{f}=A X^{\theta}$, with $A$ and $\theta$ being constants, implying that $d E_{f} / E_{f}=\theta d X / X$. Further assume that $E_{f}=(1-\tau) E$ and that $E_{d}=\tau E$, with $\tau$ being a constant between 0 and 1. Replacing all these definitions into equations (6), (7), and (8), one obtains:

$$
d L O G(S)=d S / S=\left(\mu-0.5 * \sigma^{2}\right) d t+\sigma d z-(1 /(k-g)) d k+\tau d E_{d} / E_{d}+(1-\tau) \theta d X / X
$$


If $\sigma^{2}$ varies with time and $d t=1$, then we should have:

$$
d L O G(S)=d S / S=\mu-0.5 * \sigma_{t}^{2}+\sigma_{t} d z-(1 /(k-g)) d k+\tau d E_{d} / E_{d}+(1-\tau) \theta d X / X
$$

Equation (9) can be rewritten as a regression equation in discrete time:

$$
\Delta L O G(S)=\mu+\left(\alpha * 0.5 * \sigma_{t}^{2}\right)+(\beta * \Delta k)+\tau *\left(\Delta L O G\left(E_{d}\right)\right)+\delta *(\Delta L O G(X))+\epsilon
$$

Where $\mu, \alpha, \beta, \tau$, and $\delta$ are parameters to be estimated, and $\epsilon$ is the residual. The parameter $\mu$ is the monthly drift, $\alpha$ is expected to be equal to $-1, \beta=-[1 /(D(1+g) / S)]$, with $D$ being the current dividend, and $D(1+g) / S$ being the dividend yield, and $\tau$ being between zero and +1 . The variance $\sigma_{t}^{2}$ is measured by the square of VIX, the volatility index, $k$ is measured by the Baa corporate bond yield, $E_{d}$ is measured by industrial production, and $X$ is measured by the trade-weighted dollar index. An increase in $X$ is an appreciation of the US dollar, which implies that $\theta$ and $\delta$ are negative (Azar, 2014a, and 2014b).

In the theoretical equation (10) inflation does not appear explicitly. Therefore, and if the above analysis is true, and at least theoretically, inflation has no place as an explanatory variable, and ought to be irrelevant. Any reduced form equation that does not include the variables that are present in equation (10) suffers from omitting relevant variables and cannot be validated.

\section{DATA AND METHODOLOGY}

This section is organized as follows. First, the sources of the data are acknowledged. Then, histograms of all variables are presented, that find significant outliers. Pearson correlation coefficients are calculated in subsection 3 . In the following three subsections, robust standard errors are applied, and robust least squares and quantile regressions are conducted. So far, the models are simply bilateral. In subsections 7 and 8 multilateral unconstrained regressions are carried out in conformity to the generalized theoretical model introduced in the previous section. Both robust least squares and quantile regressions are statistically run. Subsection 9 repeats the analysis by replacing CPI inflation with core inflation, in a successful attempt to provide robustness to the irrelevance proposition that was supported in subsections 3 to 8 .

\subsection{Data sources}

Monthly prices of 20 stock market portfolios are selected and retrieved from the data web site of French in which the Fama \& French stocks are located. They span the period from December 1925 to June 2020, i.e. 1,135 observations. These indices are transformed to log returns, by taking the first-difference of the natural log of their prices. From the investing.com source is retrieved the volatility index, VIX, from 1990M02 till 2020M06. The US trade-weighted foreign exchange rate of the US dollar (DOLLAR, from 1985M12 till 2020M06) is also retrieved from the same source. Monthly values of the core CPI (1956M12 till 2020M06), from which the core inflation is derived, CPI (1946M12 till 2020M06), from which CPI inflation is calculated, US industrial production (IP, 1925M12 till 2020M06), and US Moody's Baa corporate bond yield (BAA, 1925M12 till 2020M06) are retrieved from the web site of the Federal Reserve Bank of Saint Louis. The core and the CPI inflation rates are calculated by taking the first-difference of their natural logs. The DOLLAR series is converted to log returns. So is the IP variable, and the VIX. The BAA yield is differenced and is divided by 1200 , in order to get monthly decimal figures.

\subsection{Histograms}

In Figures 1, 2, and 3 are portrayed the frequency distributions in the form of histograms for all the selected series. Figure 1 is about $D(L O G(P C 5))$ till $D(L O G(P C 45))$, where $D$ is the first-difference operator, LOG is the natural logarithm, and PC is the FamaFrench percentile. Figure 2 is about $D(\operatorname{LOG}(P C 50))$ till $D(L O G(P C 90))$. Figure 3 is about $D(L O G(P C 95)), D(L O G(P C 100)), D(L O G(C P I))$, $D(B A A / 1200), D(L O G(I P)), D(L O G(D O L L A R))$, and $D(L O G(V I X))$. It is evident from the figures that there are pronounced outliers for all the 25 series. This will prompt us to choose as an econometric model Robust Least Squares with adjustment for outliers in the dependent variables and in the independent variables. Robust Least Squares is especially recommended in the presence of outliers. Since outliers affect the mean of a distribution, which renders Ordinary Least Squares biased, another econometric procedure is chosen, quantile regressions, computed around the median, granted that the median is not sensitive to outliers. As will be shown below these two econometric procedures will make a difference in significance. 
Figure 1: Histograms of the Variables Mentioned on Top of Each Graph
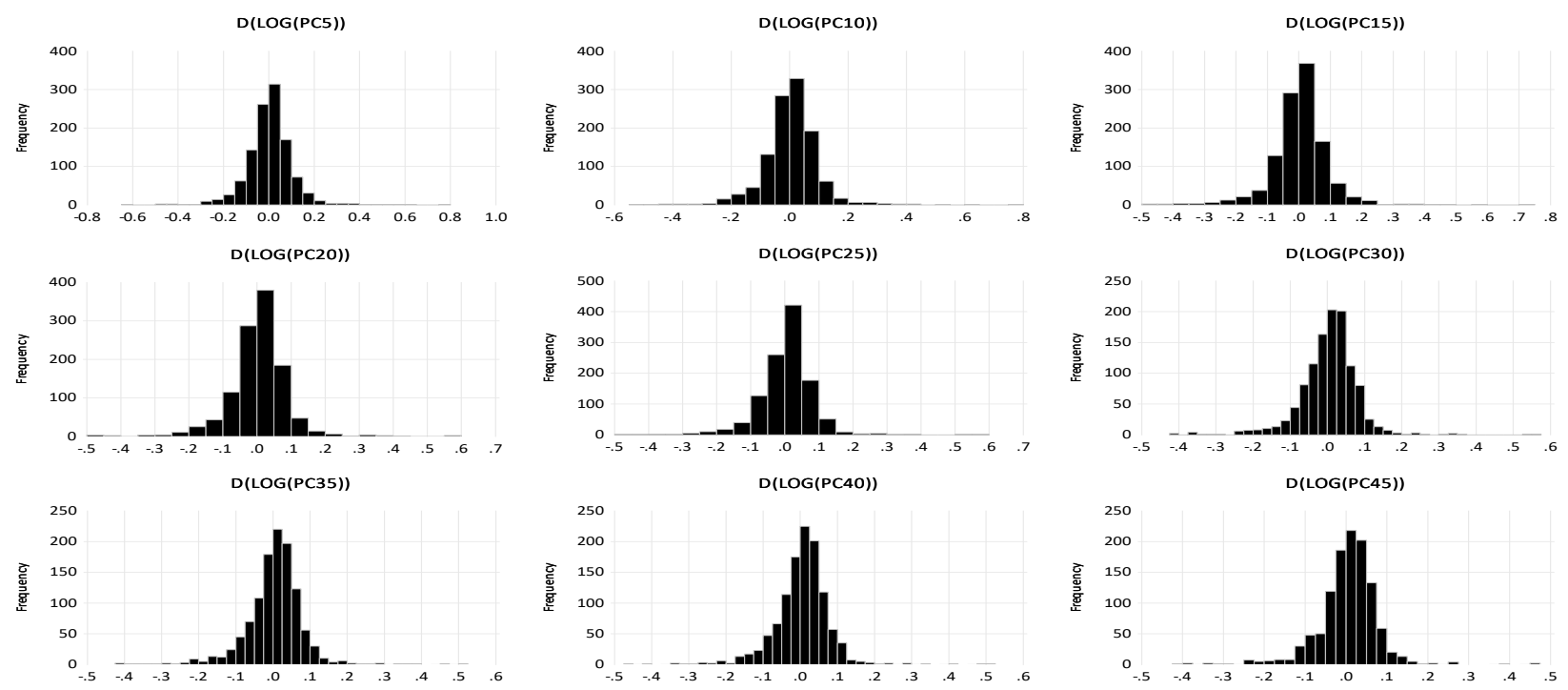

Figure 2: Histograms of the Variables Mentioned on Top of Each Graph
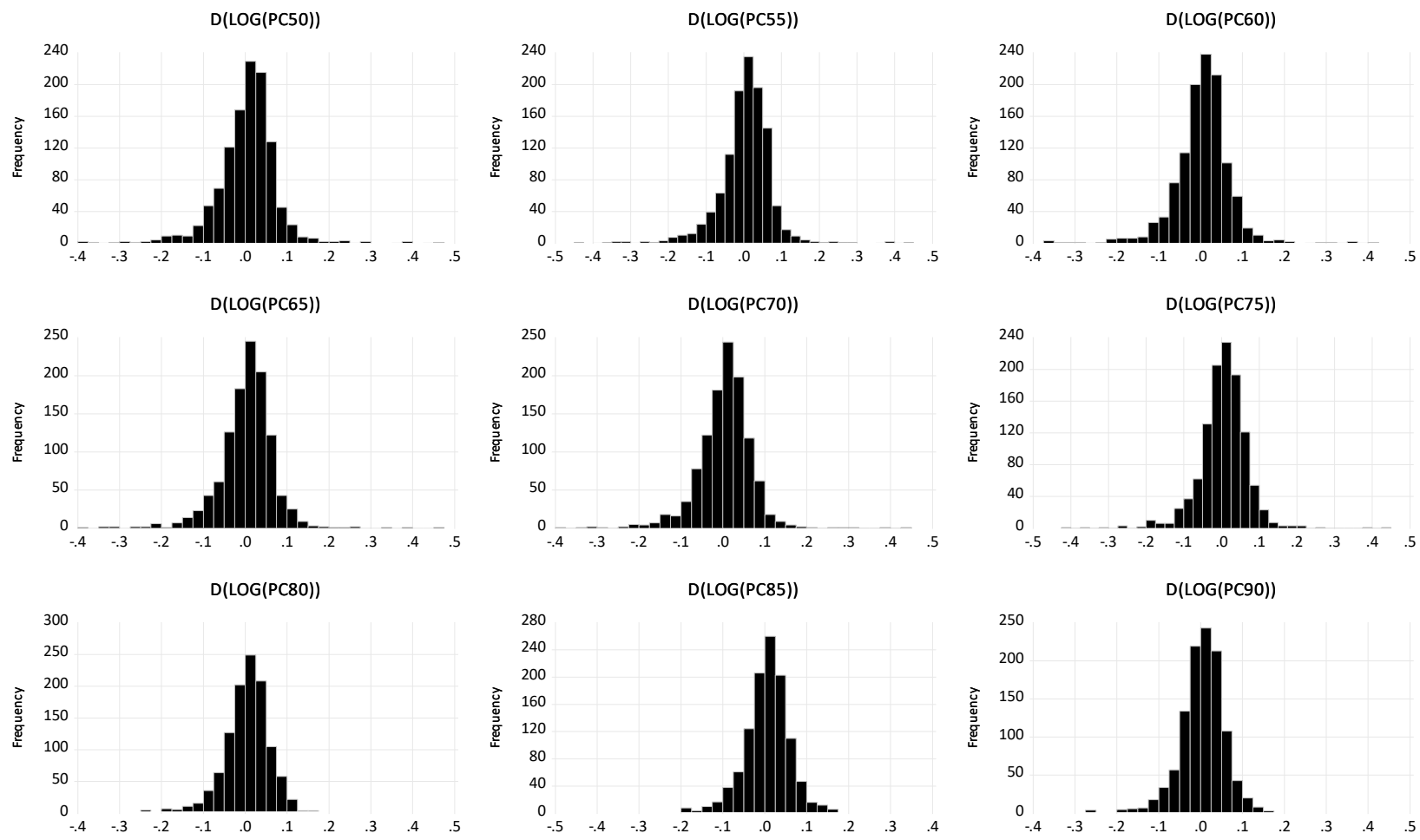
Figure 3: Histograms of the Variables Mentioned on Top of Each Graph

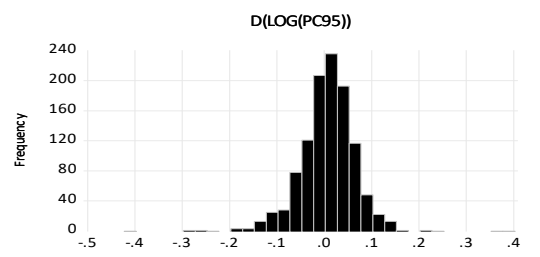

$\mathrm{D}(\mathrm{BAA} / 1200)$

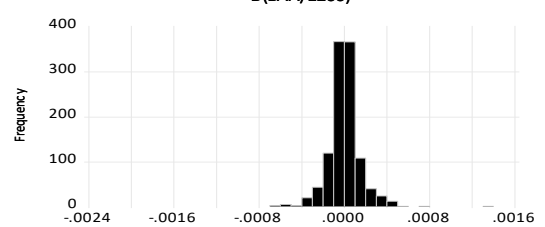

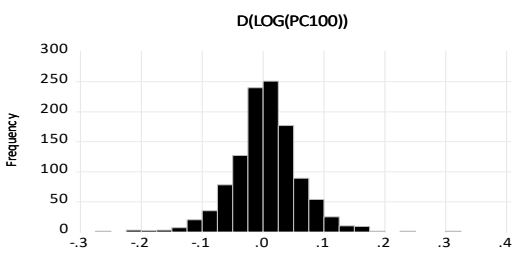

$\mathrm{D}(\mathrm{LOG}(\mathrm{IP}))$

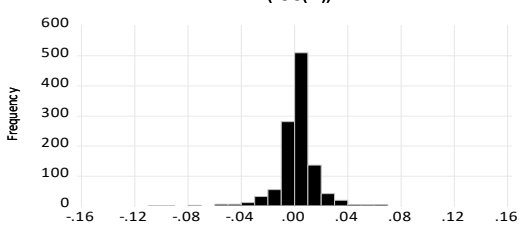

$\mathrm{D}(\operatorname{LOG}(\mathrm{VIX}))$

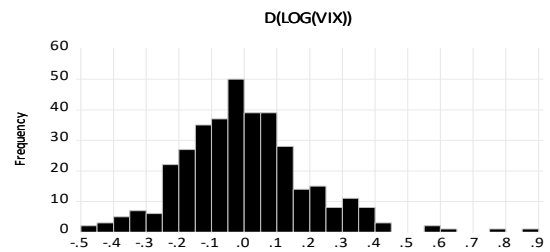

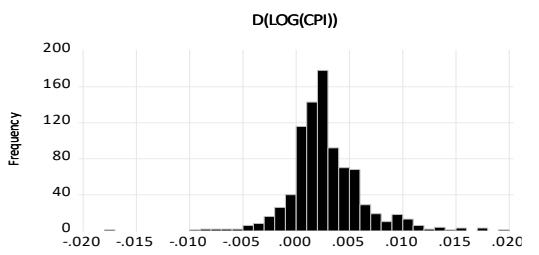

D(LOG(DOLAR))

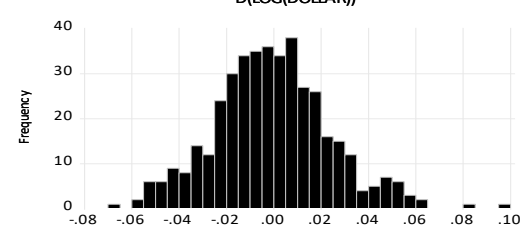

\subsection{Pearson Correlation Coefficients}

An unsophisticated investor who is studying the association between stock returns and inflation is likely to use Pearson correlation coefficients, or Ordinary Least Squares (OLS), to detect the presence of a linear bilateral relation. Since the OLS R-square is simply the square of the Pearson correlation coefficient, one may implement both procedures interchangeably. Starting from a twotailed Type I Error of 5\%, 18 out of the 20 Fama-French stocks have statistically significant correlation coefficients, the maximum actual p-value of these 18 comparisons is 0.0389 . Moreover, 19 out of 20 estimates are positive. Therefore, simple pairwise statistics would reject the null hypothesis of irrelevance of inflation quite strongly in $90 \%$ of the cases. Since OLS is the procedure that is adopted in many empirical papers an erroneous and spurious evidence is reported in support to a significant positive or sometimes negative relation of inflation.

\subsection{Regressions with HAC Robust Standard Errors and Covariance}

For such regressions, with 882 observations, the lowest actual p-value is 0.1426 which corresponds to the highest Wald F-statistic of 2.1538. The highest actual $p$-value is a lofty 0.5919 . Therefore, the null hypothesis of inflation irrelevance is very strongly supported in $100 \%$ of the cases. One would expect the signs of the inflation betas to be half-half positive and half-half negative. However, it turns out that 19 estimates out of 20 are positive and only one estimate is negative. Moreover, and to be fair, all these 19 estimates are statistically insignificantly different from +1 . It is not clear what the impact of these two anomalies has on inflation irrelevance, especially if one notices that these 19 estimates are also statistically insignificantly different from +2 !

\subsection{Regressions with Robust Least Squares}

For such robust regressions in the dependent and independent variables, with 882 observations, the lowest actual p-value is 0.1005 . The highest actual $p$-value is a grand 0.9174 . Therefore, the null hypothesis of inflation irrelevance is very strongly supported in $100 \%$ of the cases. Again, one would expect the signs of the inflation betas to be half-half positive and half-half negative. However, it turns out that 17 estimates out of the 20 are positive and only three estimates are negative. Moreover, all these 17 estimates are statistically insignificantly different from +1 . These two anomalies are not compatible with inflation irrelevance, although it is not obvious what their relative impact is. 


\subsection{Quantile Regressions on the Median}

For such regressions, with 882 observations, the lowest actual p-value is 0.2909 . The highest actual p-value is a sizeable 0.9923 . Therefore, the null hypothesis of inflation irrelevance is very strongly supported in $100 \%$ of the cases. Here again, one would expect the signs of the inflation betas to be half-half positive and half-half negative. However, it turns out, like with the previous econometric formulation, that 17 estimates out of the 20 are positive and only three estimates are negative. Moreover, like before, all these 17 estimates are statistically insignificantly different from +1 . These two anomalies are not well-suited with inflation irrelevance, although it is not apparent what their relative influence is.

\subsection{Unconstrained Regressions with Robust Least Squares}

The unconstrained regressions consist of regressing each stock log return upon the CPI inflation rate, $D(L O G(C P I))$, the change in the Baa corporate bond yield, $D(B A A / 1200)$, the log change of industrial production, $D(L O G(I P))$, the log change of the US dollar index, $D(L O G(D O L L A R))$, and the log change of the VIX volatility index (D(LOG(VIX)). The sample is from March 1990 till June 2020, i.e. 364 observations per variable. For such regressions the lowest actual p-values, that reject the null with a Type I error of $5 \%$, are five out of $20: 0.0087,0.0150,0.0218,0.0266$, and 0.0315 . The highest actual $p$-value is a considerable 0.9567 . Therefore, the null hypothesis of inflation irrelevance is supported in $75 \%$ of the cases. Again, one would expect the signs of the inflation betas to be half-half positive and half-half negative. However, it turns out that 15 estimates out of the 20 are positive and only five estimates are negative. Moreover, all these 15 estimates are statistically insignificantly different from +1 . These are two anomalies that undermine inflation irrelevance, although their relative statistical significance is not evident at all. It is noteworthy to mention that 14 out of these 15 estimates are statistically insignificantly different from +2 ! Details are in Table 1.

The monthly drift, $\mu$, is statistically significant, with an actual p-value less than $5 \%$, in 5 out of 20 cases. These are all positive and vary, in annualized terms, between $6.964 \%$ and $10.048 \%$, which are reasonable figures. There are 3 negative average returns on equity, which is unusual. Details are in Table 1. Surprisingly these unconstrained regressions yield no statistical evidence for an interest rate risk through duration. In all 20 regressions the coefficient on the change in the BAA bond yield is statistically insignificant. In addition, the estimates are flawed with the highest coefficient estimate being positive at 9.908317 instead of the predicted negative sign! Indeed, six "durations" out of 20 are positive! The lowest negative and statistically insignificant duration is -20.51180 , which stands for a dividend yield of $4.875 \%$, a rather high estimate. There is a chance that the BAA corporate bond yield is a bad proxy of the return on equity. Details are in Table 1. There are 18 coefficients out of 20 on the industrial production variable that are statistically significant, i.e. with an actual p-values less than $5 \%$. These vary between 0.470638 and 3.694792 . All coefficient estimates on the dollar variable are negative, as expected. However, there are 16 coefficients out of 20 that are statistically significant. These 16 vary between -0.327137 and -0.246755 . All coefficients on the VIX variable are negative and statistically highly significant with estimates ranging between -0.334502 and -0.105810 . The minimum $\mathrm{R}$-square is $14.1111 \%$, and the maximum is $31.1298 \%$. Details are in Table 1.

Table 1: Unconstrained MM-Estimation by Robust Least Squares. Sample: 1990M03 2020M06, i.e. 364 observations

\begin{tabular}{|c|c|c|c|c|c|c|c|}
\hline $\begin{array}{l}\text { Stock } \\
\text { return }\end{array}$ & constant & $\mathrm{D}(\mathrm{LOG}(\mathrm{CPI}))$ & D(BAA/1200) & $\mathrm{D}(\mathrm{LOG}(\mathrm{IP}))$ & D(LOG(DOLLAR)) & D(LOG(VIX)) & R-Square \\
\hline PC5 & $\begin{array}{c}-0.006450 \\
(0.1920)\end{array}$ & $\begin{array}{c}1.546559 \\
(0.3396)\end{array}$ & $\begin{array}{c}-20.51180 \\
(0.4059)\end{array}$ & $\begin{array}{c}3.694792 \\
(0.0000)\end{array}$ & $\begin{array}{c}-0.334502 \\
(0.0550)\end{array}$ & $\begin{array}{c}-0.171708 \\
(0.0000)\end{array}$ & 0.141111 \\
\hline PC10 & $\begin{array}{c}0.002337 \\
(0.5844)\end{array}$ & $\begin{array}{c}-0.455161 \\
(0.7451)\end{array}$ & $\begin{array}{c}2.525994 \\
(0.9057)\end{array}$ & $\begin{array}{c}2.697323 \\
(0.0000)\end{array}$ & $\begin{array}{c}-0.327137 \\
(0.0300)\end{array}$ & $\begin{array}{c}-0.171882 \\
(0.0000)\end{array}$ & 0.179650 \\
\hline PC15 & $\begin{array}{c}0.006948 \\
(0.0749)\end{array}$ & $\begin{array}{c}-1.197666 \\
(0.3487)\end{array}$ & $\begin{array}{c}-5.417005 \\
(0.8709)\end{array}$ & $\begin{array}{c}1.012711 \\
(0.0007)\end{array}$ & $\begin{array}{c}-0.215301 \\
(0.1176)\end{array}$ & $\begin{array}{c}-0.156300 \\
(0.0000)\end{array}$ & 0.167226 \\
\hline PC20 & $\begin{array}{c}0.007572 \\
(0.0445)\end{array}$ & $\begin{array}{c}-0.703229 \\
(0.5689)\end{array}$ & $\begin{array}{c}5.804462 \\
(0.7576)\end{array}$ & $\begin{array}{c}0.699041 \\
(0.0156)\end{array}$ & $\begin{array}{c}-0.290098 \\
(0.0290)\end{array}$ & $\begin{array}{c}-0.167309 \\
(0.0000)\end{array}$ & 0.184760 \\
\hline PC25 & $\begin{array}{c}0.008373 \\
(0.0122)\end{array}$ & $\begin{array}{c}-0.312158 \\
(0.7755)\end{array}$ & $\begin{array}{c}0.657741 \\
(0.9685)\end{array}$ & $\begin{array}{c}0.491677 \\
(0.0552)\end{array}$ & $\begin{array}{c}-0.301939 \\
(0.0104)\end{array}$ & $\begin{array}{c}-0.171616 \\
(0.000)\end{array}$ & 0.237313 \\
\hline PC30 & $\begin{array}{c}0.008207 \\
(0.0102)\end{array}$ & $\begin{array}{c}-0.152021 \\
(0.8845)\end{array}$ & $\begin{array}{c}-7.536197 \\
(0.6365)\end{array}$ & $\begin{array}{c}0.629397 \\
(0.0103)\end{array}$ & $\begin{array}{c}-0.315504 \\
(0.0051)\end{array}$ & $\begin{array}{c}-0.165538 \\
(0.0000)\end{array}$ & 0.250015 \\
\hline PC35 & $\begin{array}{c}0.007236 \\
(0.0185)\end{array}$ & $\begin{array}{c}0.048337 \\
(0.9617)\end{array}$ & $\begin{array}{c}-1.724535 \\
(0.9104)\end{array}$ & $\begin{array}{c}0.618257 \\
(0.0087)\end{array}$ & $\begin{array}{c}-0.306194 \\
(0.0047)\end{array}$ & $\begin{array}{c}-0.151195 \\
(0.0000)\end{array}$ & 0.226685 \\
\hline
\end{tabular}




\begin{tabular}{|c|c|c|c|c|c|c|c|}
\hline PC40 & $\begin{array}{c}0.001859 \\
(0.5353)\end{array}$ & $\begin{array}{c}1.155237 \\
(0.2396)\end{array}$ & $\begin{array}{c}9.908317 \\
(0.5081)\end{array}$ & $\begin{array}{c}1.333559 \\
(0.0000)\end{array}$ & $\begin{array}{c}-0.291741 \\
(0.0058)\end{array}$ & $\begin{array}{c}-0.172426 \\
(0.0000)\end{array}$ & 0.301029 \\
\hline PC45 & $\begin{array}{c}0.003099 \\
(0.2789)\end{array}$ & $\begin{array}{c}0.894254 \\
(0.3402)\end{array}$ & $\begin{array}{c}8.600778 \\
(0.5472)\end{array}$ & $\begin{array}{c}1.357367 \\
(0.0000)\end{array}$ & $\begin{array}{c}-0.286138 \\
(0.0046)\end{array}$ & $\begin{array}{c}-0.155212 \\
(0.0000)\end{array}$ & 0.257617 \\
\hline PC50 & $\begin{array}{c}0.000716 \\
(0.8013)\end{array}$ & $\begin{array}{c}1.588518 \\
(0.0885)\end{array}$ & $\begin{array}{c}4.910074 \\
(0.7297)\end{array}$ & $\begin{array}{c}1.451486 \\
(0.0000)\end{array}$ & $\begin{array}{c}-0.317317 \\
(0.0016)\end{array}$ & $\begin{array}{c}-0.150837 \\
(0.0000)\end{array}$ & 0.248981 \\
\hline PC55 & $\begin{array}{c}0.005803 \\
(0.0281)\end{array}$ & $\begin{array}{c}0.046213 \\
(0.9574)\end{array}$ & $\begin{array}{c}-9.900180 \\
(0.4528)\end{array}$ & $\begin{array}{c}0.470638 \\
(0.0203)\end{array}$ & $\begin{array}{c}-0.184275 \\
(0.0479)\end{array}$ & $\begin{array}{c}-0.154718 \\
(0.0000)\end{array}$ & 0.271350 \\
\hline PC60 & $\begin{array}{l}0.000521 \\
(0.83410\end{array}$ & $\begin{array}{c}1.752188 \\
(0.0315)\end{array}$ & $\begin{array}{c}-13.56537 \\
(0.2744)\end{array}$ & $\begin{array}{c}0.616711 \\
(0.0012)\end{array}$ & $\begin{array}{c}-0.251033 \\
(0.0042)\end{array}$ & $\begin{array}{c}-0.144063 \\
(0.0000)\end{array}$ & 0.311298 \\
\hline PC65 & $\begin{array}{c}-0.000798 \\
(0.7584)\end{array}$ & $\begin{array}{c}2.230476 \\
(0.0087)\end{array}$ & $\begin{array}{c}-12.08774 \\
(0.3505)\end{array}$ & $\begin{array}{c}1.127151 \\
(0.0000)\end{array}$ & $\begin{array}{c}-0.236796 \\
(0.0096)\end{array}$ & $\begin{array}{c}-0.141780 \\
(0.0000)\end{array}$ & 0.302943 \\
\hline PC70 & $\begin{array}{c}-0.000478 \\
(0.8528)\end{array}$ & $\begin{array}{c}1.936173 \\
(0.0218)\end{array}$ & $\begin{array}{c}-12.52330 \\
(0.3303)\end{array}$ & $\begin{array}{c}1.049661 \\
(0.0000)\end{array}$ & $\begin{array}{c}-0.278673 \\
(0.0022)\end{array}$ & $\begin{array}{c}-0.142618 \\
(0.0000)\end{array}$ & 0.297859 \\
\hline PC75 & $\begin{array}{c}0.003850 \\
(0.1274)\end{array}$ & $\begin{array}{c}0.522742 \\
(0.5275)\end{array}$ & $\begin{array}{c}-4.456719 \\
(0.7237)\end{array}$ & $\begin{array}{c}0.812882 \\
(0.0000)\end{array}$ & $\begin{array}{c}-0.300870 \\
(0.0007)\end{array}$ & $\begin{array}{c}-0.139849 \\
(0.0000)\end{array}$ & 0.281198 \\
\hline PC80 & $\begin{array}{c}0.002342 \\
(0.3447)\end{array}$ & $\begin{array}{c}0.784892 \\
(0.3338)\end{array}$ & $\begin{array}{c}-5.118416 \\
(0.6792)\end{array}$ & $\begin{array}{c}0.818493 \\
(0.0000)\end{array}$ & $\begin{array}{c}-0.219468 \\
(0.0121)\end{array}$ & $\begin{array}{c}-0.140851 \\
(0.0000)\end{array}$ & 0.307442 \\
\hline PC85 & $\begin{array}{c}0.001550 \\
(0.5248)\end{array}$ & $\begin{array}{c}1.442175 \\
(0.0709)\end{array}$ & $\begin{array}{c}-17.43471 \\
(0.1518)\end{array}$ & $\begin{array}{c}0.684802 \\
(0.0003)\end{array}$ & $\begin{array}{c}-0.157501 \\
(0.0669)\end{array}$ & $\begin{array}{c}-0.130703 \\
(0.0000)\end{array}$ & 0.292901 \\
\hline PC90 & $\begin{array}{c}0.001716 \\
(0.4581)\end{array}$ & $\begin{array}{c}1.679975 \\
(0.0266)\end{array}$ & $\begin{array}{c}-17.82398 \\
(0.1226)\end{array}$ & $\begin{array}{c}0.885316 \\
(0.0000)\end{array}$ & $\begin{array}{c}-0.220566 \\
(0.0068)\end{array}$ & $\begin{array}{c}-0.122892 \\
(0.0000)\end{array}$ & 0.305942 \\
\hline PC95 & $\begin{array}{c}0.000699 \\
(0.8055)\end{array}$ & $\begin{array}{c}2.261932 \\
(0.0150)\end{array}$ & $\begin{array}{c}-13.57426 \\
(0.3382)\end{array}$ & $\begin{array}{c}0.418114 \\
(0.0550)\end{array}$ & $\begin{array}{c}-0.188664 \\
(0.0595)\end{array}$ & $\begin{array}{c}-0.139591 \\
(0.0000)\end{array}$ & 0.266319 \\
\hline PC100 & $\begin{array}{c}0.003807 \\
(0.2322)\end{array}$ & $\begin{array}{c}0.325219 \\
(0.7554)\end{array}$ & $\begin{array}{c}-8.571705 \\
(0.5899)\end{array}$ & $\begin{array}{c}0.535514 \\
(0.0285)\end{array}$ & $\begin{array}{c}-0.206784 \\
(0.0657)\end{array}$ & $\begin{array}{c}-0.105810 \\
(0.0000)\end{array}$ & 0.167512 \\
\hline
\end{tabular}

Actual $p$-values in parentheses.

\subsection{Unconstrained Quantile Regressions}

For such regressions the lowest actual $p$-value out of 20 is 0.055 , failing to reject the null of inflation irrelevance. The highest actual $p$-value is a substantial 0.9267 . Therefore, the null hypothesis of inflation irrelevance is very strongly supported in $100 \%$ of the cases. Again, one would expect the signs of the inflation betas to be half-half positive and half-half negative. However, it turns out that 18 estimates out of the 20 are positive and only two estimates are negative. Moreover, all these 18 estimates are statistically insignificantly different from +1 . Therefore, there are two anomalies that falsify inflation irrelevance, but their relative statistical significance is not straightforward. It is noteworthy to mention that all these 18 estimates are also statistically insignificantly different from +2 ! Details are in Table 2 . The monthly drift, $\mu$, is consistently statistically insignificant, with actual $p$ values more than $5 \%$. In 4 out of 20 cases the estimates are negative. Surprisingly these unconstrained regressions yield no statistical evidence for an interest rate risk through duration. In all 20 regressions the coefficient on the change in the BAA bond yield is statistically insignificant. In addition, the estimates are flawed with the highest coefficient estimate being positive at 20.73893 instead of the predicted negative sign! Indeed, four "durations" out of 20 are positive! The lowest negative and statistically insignificant duration is -25.21191 , which stands for a dividend yield of $3.966 \%$, a reasonable estimate. But all other estimates are higher than this figure. As already mentioned, there is a chance that the BAA corporate bond yield is a bad proxy of the return on equity. Details are in Table 2. There are 4 coefficients out of 20 on the industrial production variable that are statistically significant, i.e. with actual p-values less than $5 \%$. These vary between 0.392693 and 3.152701 . All coefficient estimates on the dollar variable are negative, as expected. However, there are 9 coefficients out of 20 that are statistically significant. These nine vary between -0.408748 and -0.157501 . All coefficients on the VIX variable are negative and statistically highly significant with estimates ranging between -0.182768 and -0.097939 . The minimum R-square is $10.8884 \%$, and the maximum is $22.2173 \%$. Details are in Table 2. 
Table 2: Unconstrained Estimation by Quantile Regressions at the Median

Sample: 1990M03 2020M06, i.e. 364 observations.

\begin{tabular}{|c|c|c|c|c|c|c|c|}
\hline $\begin{array}{l}\text { Stock } \\
\text { return }\end{array}$ & constant & D(LOG(CPI)) & $\mathrm{D}(\mathrm{BAA} / \mathbf{1 2 0 0 )}$ & $\mathrm{D}(\mathrm{LOG}(\mathrm{IP}))$ & $\mathrm{D}($ LOG(DOLLAR)) & $\mathrm{D}(\mathrm{LOG}(\mathrm{VIX}))$ & R-Square \\
\hline PC5 & $\begin{array}{c}-0.009823 \\
(0.2529)\end{array}$ & $\begin{array}{c}3.231722 \\
(0.1674)\end{array}$ & $\begin{array}{c}-16.26011 \\
(0.5242)\end{array}$ & $\begin{array}{c}3.152701 \\
(0.1154)\end{array}$ & $\begin{array}{c}-0.270373 \\
(0.2372)\end{array}$ & $\begin{array}{c}-0.163506 \\
(0.0000)\end{array}$ & 0.108941 \\
\hline PC10 & $\begin{array}{c}0.006168 \\
(0.4250)\end{array}$ & $\begin{array}{c}-0.278373 \\
(0.8933)\end{array}$ & $\begin{array}{c}-16.73553 \\
(0.4812)\end{array}$ & $\begin{array}{c}2.129381 \\
(0.1428)\end{array}$ & $\begin{array}{c}-0.377330 \\
(0.0877)\end{array}$ & $\begin{array}{c}-0.149564 \\
(0.0000)\end{array}$ & 0.128842 \\
\hline PC15 & $\begin{array}{c}0.000655 \\
(0.9190)\end{array}$ & $\begin{array}{c}1.578924 \\
(0.3499)\end{array}$ & $\begin{array}{c}-9.657859 \\
(0.6613)\end{array}$ & $\begin{array}{c}1.670957 \\
(0.1121)\end{array}$ & $\begin{array}{c}-0.189504 \\
(0.3622)\end{array}$ & $\begin{array}{c}-0.141702 \\
(0.0000)\end{array}$ & 0.122007 \\
\hline PC20 & $\begin{array}{c}0.003092 \\
(0.6104)\end{array}$ & $\begin{array}{c}-0.152193 \\
(0.9267)\end{array}$ & $\begin{array}{c}10.77973 \\
(0.6822)\end{array}$ & $\begin{array}{c}1.377506 \\
(0.2190)\end{array}$ & $\begin{array}{c}-0.401364 \\
(0.0319)\end{array}$ & $\begin{array}{c}-0.183662 \\
(0.0000)\end{array}$ & 0.150312 \\
\hline PC25 & $\begin{array}{c}0.002658 \\
(0.6424)\end{array}$ & $\begin{array}{c}1.269385 \\
(0.3772)\end{array}$ & $\begin{array}{c}-2.171092 \\
(0.9293)\end{array}$ & $\begin{array}{c}1.145217 \\
(0.2276)\end{array}$ & $\begin{array}{c}-0.340864 \\
(0.0275)\end{array}$ & $\begin{array}{c}-0.182768 \\
(0.0000)\end{array}$ & 0.181358 \\
\hline РC30 & $\begin{array}{c}0.001424 \\
(0.8382)\end{array}$ & $\begin{array}{c}1.793500 \\
(0.2655)\end{array}$ & $\begin{array}{c}-10.91455 \\
(0.6474)\end{array}$ & $\begin{array}{c}1.469874 \\
(0.2759)\end{array}$ & $\begin{array}{c}-0.315507 \\
(0.0341)\end{array}$ & $\begin{array}{c}-0.164675 \\
(0.0000)\end{array}$ & 0.185259 \\
\hline PC35 & $\begin{array}{c}0.001436 \\
(0.8084)\end{array}$ & $\begin{array}{c}0.808621 \\
(0.5818)\end{array}$ & $\begin{array}{c}-10.74763 \\
(0.5522)\end{array}$ & $\begin{array}{c}1.327423 \\
(0.1645)\end{array}$ & $\begin{array}{c}-0.408748 \\
(0.0187)\end{array}$ & $\begin{array}{c}-0.150023 \\
(0.0000)\end{array}$ & 0.173112 \\
\hline PC40 & $\begin{array}{c}-0.000076 \\
(0.9893)\end{array}$ & $\begin{array}{c}1.355647 \\
(0.3692)\end{array}$ & $\begin{array}{c}-3.677903 \\
(0.8276)\end{array}$ & $\begin{array}{c}0.912652 \\
(0.2429)\end{array}$ & $\begin{array}{c}-0.200113 \\
(0.1989)\end{array}$ & $\begin{array}{c}-0.169129 \\
(0.0000)\end{array}$ & 0.209386 \\
\hline PC45 & $\begin{array}{c}0.003627 \\
(0.4301)\end{array}$ & $\begin{array}{c}1.072488 \\
(0.3552)\end{array}$ & $\begin{array}{c}3.393143 \\
(0.8303)\end{array}$ & $\begin{array}{c}1.410749 \\
(0.0559)\end{array}$ & $\begin{array}{c}-0.244064 \\
(0.0683)\end{array}$ & $\begin{array}{c}-0.173512 \\
(0.0000)\end{array}$ & 0.204904 \\
\hline PC50 & $\begin{array}{c}0.001841 \\
(0.6834)\end{array}$ & $\begin{array}{c}1.855817 \\
(0.1052)\end{array}$ & $\begin{array}{c}-6.168831 \\
(0.7432)\end{array}$ & $\begin{array}{c}1.382883 \\
(0.0547)\end{array}$ & $\begin{array}{c}-0.246755 \\
(0.0314)\end{array}$ & $\begin{array}{c}-0.147580 \\
(0.0000)\end{array}$ & 0.205359 \\
\hline PC55 & $\begin{array}{c}-0.001671 \\
(0.7209)\end{array}$ & $\begin{array}{c}2.138977 \\
(0.1201)\end{array}$ & $\begin{array}{c}-6.017838 \\
(0.6886)\end{array}$ & $\begin{array}{c}1.297370 \\
(0.1110)\end{array}$ & $\begin{array}{c}-0.183641 \\
(0.1140)\end{array}$ & $\begin{array}{c}-0.159314 \\
(0.0000)\end{array}$ & 0.199517 \\
\hline PC60 & $\begin{array}{c}-0.000617 \\
(0.8869)\end{array}$ & $\begin{array}{c}2.142224 \\
(0.0753)\end{array}$ & $\begin{array}{c}-3.700172 \\
(0.8440)\end{array}$ & $\begin{array}{c}1.011446 \\
(0.1640)\end{array}$ & $\begin{array}{c}-0.119835 \\
(0.3108)\end{array}$ & $\begin{array}{c}-0.150956 \\
(0.0000)\end{array}$ & 0.222173 \\
\hline PC65 & $\begin{array}{c}0.000671 \\
(0.8703)\end{array}$ & $\begin{array}{c}1.790720 \\
(0.1807)\end{array}$ & $\begin{array}{c}-12.72991 \\
(0.4840)\end{array}$ & $\begin{array}{c}1.341462 \\
(0.0000)\end{array}$ & $\begin{array}{c}-0.212979 \\
(0.0617)\end{array}$ & $\begin{array}{c}-0.140537 \\
(0.0000)\end{array}$ & 0.201112 \\
\hline PC70 & $\begin{array}{c}0.001520 \\
(0.7473)\end{array}$ & $\begin{array}{c}1.343726 \\
(0.3534)\end{array}$ & $\begin{array}{c}-13.34049 \\
(0.5694)\end{array}$ & $\begin{array}{c}1.172475 \\
(0.1409)\end{array}$ & $\begin{array}{c}-0.267218 \\
(0.0485)\end{array}$ & $\begin{array}{c}-0.138009 \\
(0.0000)\end{array}$ & 0.216010 \\
\hline PC75 & $\begin{array}{c}0.003326 \\
(0.3571)\end{array}$ & $\begin{array}{c}0.467943 \\
(0.7032)\end{array}$ & $\begin{array}{c}0.893124 \\
(0.9654)\end{array}$ & $\begin{array}{c}0.985007 \\
(0.0000)\end{array}$ & $\begin{array}{c}-0.317069 \\
(0.0023)\end{array}$ & $\begin{array}{c}-0.134564 \\
(0.0000)\end{array}$ & 0.205218 \\
\hline PC80 & $\begin{array}{c}0.003029 \\
(0.5037)\end{array}$ & $\begin{array}{c}0.688042 \\
(0.5869)\end{array}$ & $\begin{array}{c}-4.068640 \\
(0.8352)\end{array}$ & $\begin{array}{c}0.815546 \\
(0.1403)\end{array}$ & $\begin{array}{c}-0.251771 \\
(0.0219)\end{array}$ & $\begin{array}{c}-0.133745 \\
(0.0000)\end{array}$ & 0.211496 \\
\hline PC85 & $\begin{array}{c}0.000925 \\
(0.7942)\end{array}$ & $\begin{array}{c}1.637923 \\
(0.1186)\end{array}$ & $\begin{array}{c}-25.21191 \\
(0.0849)\end{array}$ & $\begin{array}{c}0.392693 \\
(0.3718)\end{array}$ & $\begin{array}{c}-0.116433 \\
(0.3641)\end{array}$ & $\begin{array}{c}-0.131214 \\
(0.0000)\end{array}$ & 0.207858 \\
\hline PC90 & $\begin{array}{c}0.003829 \\
(0.2137)\end{array}$ & $\begin{array}{c}2.303456 \\
(0.0550)\end{array}$ & $\begin{array}{c}-18.78467 \\
(0.1535)\end{array}$ & $\begin{array}{c}0.784305 \\
(0.1511)\end{array}$ & $\begin{array}{c}-0.186342 \\
(0.0856)\end{array}$ & $\begin{array}{c}-0.130903 \\
(.0000)\end{array}$ & 0.227129 \\
\hline PC95 & $\begin{array}{c}0.002088 \\
(0.6229)\end{array}$ & $\begin{array}{c}1.878145 \\
(0.1678)\end{array}$ & $\begin{array}{c}-7.860511 \\
(0.7645)\end{array}$ & $\begin{array}{c}0.548738 \\
(0.0024)\end{array}$ & $\begin{array}{c}-0.171014 \\
(0.2156)\end{array}$ & $\begin{array}{c}-0.133254 \\
(0.0000)\end{array}$ & 0.167678 \\
\hline PC100 & $\begin{array}{c}0.002902 \\
(0.4031)\end{array}$ & $\begin{array}{c}0.399909 \\
(0.6858)\end{array}$ & $\begin{array}{c}20.73893 \\
(0.1840)\end{array}$ & $\begin{array}{c}0.573614 \\
(0.0021)\end{array}$ & $\begin{array}{c}-0.244686 \\
(0.0413)\end{array}$ & $\begin{array}{c}-0.097939 \\
(0.0000)\end{array}$ & 0.108884 \\
\hline
\end{tabular}

Actual $p$-values in parentheses.

This part of the paper will dwell also on constrained and unconstrained models. Constrained models include only inflation as an independent variable, whereas unconstrained models include the 5 identified independent variables. First, bilateral constrained correlation coefficients are computed. There are two coefficients that are statistically insignificant out of the 20 . The maximum actual $p$-value for these 18 coefficients is 0.0389 . All 20 coefficients are negative, which is a bad signal. This feature contrasts with the results of CPI inflation which are almost all positive. It is as if there is a balance or trade-off between estimates. An 
unsophisticated investor would conclude that inflation is non-neutral. However, this is contradicted by further analysis. The lowest actual Wald $p$-value for HAC regressions is 0.1007 , failing to reject inflation irrelevance in $100 \%$ of the cases. Quantile regressions produce 4 actual $p$-values that are statistically significant: $0.0019,0.0143,0.0278$, and 0.0364 . This is additional evidence on inflation irrelevance in $80 \%$ of the cases. Robust Least squares depict a different picture for constrained models as 15 regressions have statistically significant $p$-values. Unconstrained regressions are much more and much more strongly supportive of inflation irrelevance. The lowest actual p-value on including inflation for unconstrained MM Robust Least Squares is 0.2590. And the lowest actual $p$-value on including inflation for unrestricted quantile regressions is 0.2742 . Hence inflation irrelevance is supported by $100 \%$ in both cases.

\section{CONCLUSION}

The association between stock returns and inflation is challenging, debatable, and controversial. The generalized Fisher's theory predicts a positive one-to-one relation, as nominal rates of return change proportionately with expected inflation. Moreover, stocks are considered to be hedges against fluctuations in the prices of real assets. Early empirical evidence found a statistically significant but negative relation. Lately, the evidence has swayed towards inflation irrelevance. Although most Pearson correlation coefficients of stock returns with CPI and core inflation rates are statistically significant, the coefficient estimates with CPI inflation are mostly positive while those with core inflation are all negative, casting doubt on the stability of the underlying relation. Applying HAC standard errors with least squares, using robust least squares, and running quantile regressions reverse the evidence, and support inflation irrelevance in $100 \%$ of the cases. One adds to these constrained models the results with unconstrained regressions which favor inflation irrelevance in $75 \%$ of the cases, using robust Least Squares, and in $100 \%$ of the cases using quantile regressions. Therefore, there is very strong evidence on inflation irrelevance. This means that no money illusion or other inefficiencies, no tax effects, and no derived money demand explanation, exist and that there is no need to appeal to the fiscal/monetary nexus. Stock prices are NPVs, where real cash flows are discounted by real rates and nominal cash flows discounted by nominal rates, thereby giving the same value for both.

\section{REFERENCES}

Al-Nassar, N. S., \& Bhatti, R. H. (2019). Are common stocks a hedge against inflation in emerging markets? Journal of Economics and Finance, 135.

Anari, A., \& Kolari, J. (2001). Stock prices and inflation. Journal of Financial Research, 24(4), 587-602. https://doi.org/10.1111/j.14756803.2001.tb00832.x

Azar, S. A. (2010). Inflation and stock returns. International Journal of Accounting and Finance, 2(3-4), 254-274. https://doi.org/10.1504/IJAF.2010.034399

Azar, S. A. (2013). The spurious relation between inflation uncertainty and stock returns: evidence from the US. Review of Economics \& Finance, 3 , 99-109.

Azar, S. A. (2014a). The determinants of US stock market returns. Open Economics and Management Journal, 1(1), 1-13. https://doi.org/10.2174/2352630001401010001

Azar, S. A. (2014b). Inflation and stock returns II. International Journal of Economics and Finance, 6(1), $208-216$. https://doi.org/10.5539/ijef.v6n1p208

Azar, S. A. (2015). The equity premium and inflation: Evidence from the US. Applied Finance and Accounting, 1, 1, 30-36.

Azar, S. A. (2020a). Irrelevance of Inflation and Inflation Uncertainty to Stock Returns, Book Publisher International (India and UK).

Azar, S. A. (2020b). Hypothesis testing when the same variable appears on both sides of the regression, The Empirical Economics Letters, 19(3), 221-225.

Azar, S. A. (2020c). Irrelevance of inflation: The Dow stocks. Accounting and Finance Research. 9, 1, 45-66. https://doi.org/10.5430/afr.v9n1p45

Azar, S. A. (2020d). Irrelevance of Inflation: Six Stock Market Indices, Book Publisher International (India and UK).

Boamah, M. I. (2017). Common stocks and inflation: an empirical analysis of G7 and BRICS. Atlantic Economic Journal, 45(2), $213-224$. https://doi.org/10.1007/s11293-017-9543-9

Bodie, Z. (1976). Common stocks as a hedge against inflation. The Journal of Finance, 31(2), 459-470. https://doi.org/10.1111/j.15406261.1976.tb01899.x 
Boudoukh, J., \& Richardson, M. (1993). Stock returns and inflation: A long-horizon perspective. The American economic review, 83(5), $1346-1355$. Brealey, R. A., Myers, S. C., \& Allen, F. (2017) Principles of Corporate Finance, McGraw-Hill, $12^{\text {th }}$ edition.

Campbell, J. Y., \& Vuolteenaho, T. (2004). Inflation illusion and stock prices. American Economic Review, 94(2), 19-23. https://doi.org/10.1257/0002828041301533

Crosby, M. (2001). Stock returns and inflation. Australian Economic Papers, 40(2), 156-165.

Eldomiaty, T., Saeed, Y., Hammam, R., \& AboulSoud, S. (2020). The associations between stock prices, inflation rates, interest rates are still persistent. Empirical evidence from stock duration model. Journal of Economics, Finance and Administrative Science, $25(49), 149-162$.

Ely, D. P., \& Robinson, K. J. (1997). Are stocks a hedge against inflation? International evidence using a long-run approach. Journal of International Money and Finance, 16(1), 141-167. https://doi.org/10.1016/S0261-5606(96)00039-3

Engle, R. F., \& Granger, C. W. (1987). Co-integration and error correction: representation, estimation, and testing. Econometrica: Journal of the Econometric Society, 251-276. https://doi.org/10.2307/1913236

Fama, E. F. (1981). Stock returns, real activity, inflation, and money. The American Economic Review, 71(4), 545-565.

Fama, E. F., \& French, K. R. (2002). The equity premium. The Journal of Finance, 57(2), 637-659. https://doi.org/10.1111/1540-6261.00437

Fama, E. F., \& Schwert, G. W. (1977). Asset returns and inflation. Journal of Financial Economics, 5(2), 115-146. https://doi.org/10.1016/0304$405 \times(77) 90014-9$

Feldstein, M. (1980). Inflation, tax rules and the stock market. Journal of Monetary Economics, 6(3), 309-331. https://doi.org/10.1016/03043932(80)90045-8

Fisher, I. (1930). The Theory of Interest, as Determined by Impatience to Spend Income and Opportunity to Invest it. New York: Macmillan.

Geske, R., \& Roll, R. (1983). The fiscal and monetary linkage between stock returns and inflation. The Journal of Finance, $38(1)$, 1-33. https://doi.org/10.1111/j.1540-6261.1983.tb03623.x

Gordon, M. J. (1959). Dividends, earnings and stock prices. Review of Economics and Statistics, 41, (2), 99-105.

Gordon, M. J. (1962). The investment, financing, and valuation of the corporation. Homewood, IL: RD Irwin.

Gordon, M. J., and Shapiro, E. (1956). Capital equipment analysis: The required rate of profit. Management Science, 3, (1), 102-110

Gultekin, N. B. (1983). Stock market returns and inflation: evidence from other countries. The Journal of Finance, 38(1), 49-65. https://doi.org/10.1111/j.1540-6261.1983.tb03625.x

Harper, A. and Jin, Z. (2012). Stock returns and macroeconomic factors: An examination of the Indonesian domestic economy. International Research Journal of Applied Finance, 3, 4, 426-434.

Hasan, M. S. (2008). Stock returns, inflation and interest rates in the United Kingdom. The European Journal of Finance, 14(8), 687-699.

Jaffe, J. F., \& Mandelker, G. (1976). The" Fisher effect" for risky assets: An empirical investigation. The Journal of Finance, 31(2), 447-458. https://doi.org/10.1111/j.1540-6261.1976.tb01898.x https://doi.org/10.2307/2326616

Jareño, F., \& Navarro, E. (2010). Stock interest rate risk and inflation shocks. European Journal of Operational Research, 201(2), 337-348.

Leibowitz, M. L., Sorensen, E. H., Arnott, R. D., and Hanson, N. (1989). A total differential approachto equity duration. Financial Analysts Journal, $45,(5), 30-37$.

Modigliani, F., \& Cohn, R. A. (1979). Inflation, rational valuation and the market. Financial Analysts Journal, 35(2), 24-44. https://doi.org/10.2469/faj.v35.n2.24

Nelson, C. R. (1976). Inflation and rates of return on common stocks. The Journal of Finance, 31(2), 471-483. https://doi.org/10.1111/j.15406261.1976.tb01900.x

Solnik, B. (1983). The relation between stock prices and inflationary expectations: the international evidence. The Journal of Finance, 38(1), 3548. https://doi.org/10.1111/j.1540-6261.1983.tb03624.x

Williams, J. B. (1938). The Theory of Investment Value, Fraser Publishing, Cambridge: Harvard University Press. 